DOI: https://doi.org/10.31933/dijemss.v2i2 Received: 16 September 2020, Revised: 25 November 2020, Publish:15 December 2020

\begin{tabular}{|c|c|c|}
\hline PINASTISHR & $\begin{array}{l}\text { DIJEMSS } \\
\text { DINASTI INTERNATIONAL JOURNAL } \\
\text { OF EDUCATION MANAGEMENT AND } \\
\text { SOCIAL SCIENCE }\end{array}$ & $\begin{array}{r}\text { https:I/dinastipub.org/DIJEMSS } \\
\text { editor@dinastipub.org } \\
08117401455 @\end{array}$ \\
\hline
\end{tabular}

\title{
STRATEGY FOR MANAGING WORKLOADS OF AIR TRAFFIC CONTROLLER AT PERUM LPPNPI
}

\author{
Ari Satria Saputra ${ }^{1}$ \\ 1) Mercu Buana University, Jakarta, Indonesia, arisatria@live.com
}

Corresponding Author: Ari Satria Saputra ${ }^{1}$

\begin{abstract}
This study aims to analyze workload management strategies, constraints in workload management strategies and planning and development of air traffic integration workload management strategies at Perum LPPNPI. Research data is data collected from interviews, literature studies and data observations obtained from the directorate of operations of the Perum LPPNPI office and evaluation of air navigation over a period of years to years. This type of research is a qualitative descriptive study that has a complete picture of a phenomenon or event that occurs according to its purpose. The method used by researchers in analyzing data is data collection, data reduction, data display and conclusion. Subjects in this study were 5 (five) sources as officials on duty at Perum LPPNPI. The results of this study indicate that the air traffic workload management strategy at Perum LPPNPI is in fulfilling the number of human resources and needs, restructuring air space, managing ATFM (Air Traffic Flow Management), paying more attention to FRMS (Fatigue Risk Management System).
\end{abstract}

Keywords: Strategy, Workload, Perum LPPNPI, Air Traffic Control

\section{INTRODUCTION}

Indonesia is a country that has the largest area compared to 10 other countries in the Southeast Asia region. From a geographical point of view, Indonesia is directly adjacent to Malaysia, Singapore, the Philippines and the South China Sea to the north; Australia, Timor Leste and the Indonesian Ocean to the south; The Indonesian Ocean in the west; and Papua New Guinea, Timor Leste and the Pacific Ocean to the east. This makes Indonesia geographically an important role for transportation traffic to and from Asia and Australia.

Inseparable from these factors, air space is also part of the sovereignty of the Republic of Indonesia which is located above land space and or ocean space around the territory of the state and is attached to the earth where a country has jurisdiction rights. Land space, ocean space and air space constitute a unitary space that cannot be separated. Most countries in the world, including Indonesia, have ratified the 1944 Geneva Convention (Convention on International Civil Aviation) so that Indonesia adheres to the understanding that each country 
has complete and exclusive sovereignty over the air space above its territory, and there is no recognition of the right of peaceful passage. So not a single foreign aircraft is allowed to pass through the national air space of a country without the permission of the country concerned.

Airspace regulation in Indonesia based on Law number 1 of 2009 concerning Aviation and Government Regulation (PP) number 77 of 2012 is managed by a Public Company (Perum) Indonesian Aviation Navigation Service Provider Agency (LPPNPI) or commonly called AirNav Indonesia, which was previously handled directly by PT Angkasa Pura I (Persero) and PT Angkasa Pura II (Persero) as well as the Ministry of Transportation which manages the Technical Service Unit airports throughout Indonesia.

With the establishment of Perum LPPNPI, safety and flight navigation services can be well organized because previously navigation services in Indonesia were served by the UPT Directorate General of Transportation, PT Angkasa Pura I (Persero), PT Angkasa Pura II (Persero), and special airports that led to the existence of differences in the level of quality of navigation services and the lack of focus of flight navigation service providers. Perum LPPNPI capital ownership is fully owned by the Republic of Indonesia, which in this case is represented by the Ministry of BUMN. Meanwhile, the Ministry of Transportation acts as a regulator. As a Public Company that aims to improve flight navigation services in Indonesia, Perum LPPNPI carries out a Business Process by means of Cost Recovery.

Perum LPPNPI is divided into 2 air spaces based on the Flight Information Region (FIR), namely FIR Jakarta which is centered at the JATSC Branch Office (Jakarta Air Traffic Services Center) and FIR Ujung Pandang which is centered at the MATSC Branch Office (Makassar Air Traffic Services Center). The total area of the FIR $=5,193,252 \mathrm{~km} 2$; Area $=$ 4,110,752 km2, with the number of flight traffic: 10,000 movements / day. The operational area of Perum LPPNPI is directly adjacent to FIR Melbourne and Brisbane (Australia), FIR Colombo (Srilanka), FIR Singapore, FIR Kuala Lumpur and Kinabalu (Malaysia, FIR Manila (Philippines), FIR Oakland (United States), FIR Port Moresby (Papua) New Guinea) and FIR Chennai (India). Perum LPPNPI is a milestone in the world of Indonesian national aviation, because Perum LPPNPI is the only aviation navigation operator in Indonesia. Based on PP No. 77 of 2012 the purpose and objective of establishing Perum LPPNPI is to provide aviation navigation services in accordance with applicable standards to achieve flight efficiency and effectiveness in the national and international scope. Perum LPPNPI serves flight navigation services, including air traffic services, aviation telecommunications services, aeronautical information services, flight meteorological information services, search and rescue information services. As a Business Entity, the performance benchmark of Perum LPPNPI is seen from the aspect of aviation safety which consists of many elements such as human resources, equipment, procedures and so on, all of which must follow developments and standards that are strictly regulated in the Civil Aviation Safety Regulations (CASR).

Since the establishment of Perum LPPNPI, it is recorded that the total flight traffic in Indonesia has been increasing every year. The following is the data that the authors obtained from the Division of Air Navigation Service Data and Evaluation. 
Table 1.1 Air Traffic Movement Data in Indonesia

\begin{tabular}{|l|l|l|l|l|l|l|}
\hline Flight & $\mathbf{2 0 1 3}$ & $\mathbf{2 0 1 4}$ & $\mathbf{2 0 1 5}$ & $\mathbf{2 0 1 6}$ & $\mathbf{2 0 1 7}$ & $\mathbf{2 0 1 8}$ \\
\hline Domestic & 1337887 & 1449677 & 1692438 & 1935172 & 2067050 & 2178346 \\
\hline International & 186131 & 246526 & 194286 & 200231 & 217652 & 231864 \\
\hline Total & 1524018 & 1696203 & 1886724 & 2135403 & 2284702 & 2410210 \\
\hline
\end{tabular}

Source: Division of Air Navigation Data and Evaluation Services (2019)

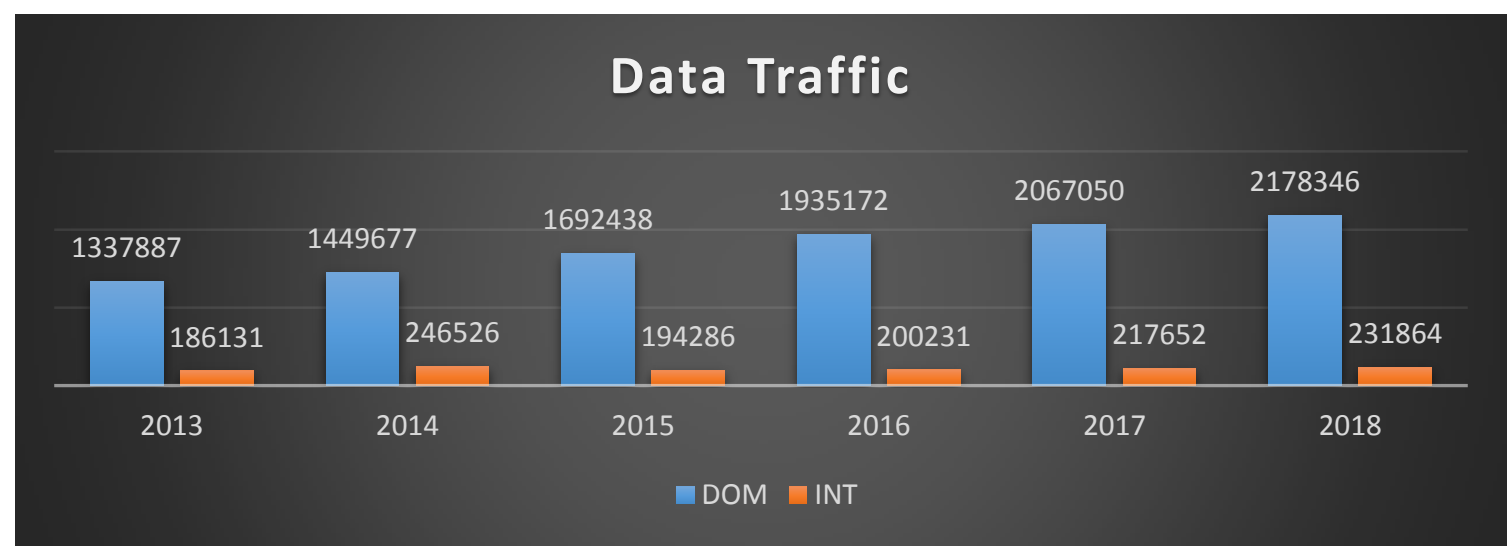

Figure 1.1 Air Traffic Movement in Indonesia

Source: Division of Air Navigation Data and Evaluation Services (2019)

Based on the data obtained by the author, it can be concluded that there has been an increase in flight traffic every year since the LPPNPI Public Corporation was first established. This is a big challenge for Perum LPPNPI in carrying out its duties as the only provider of flight navigation services in Indonesia.

In facing the challenges of increasing air traffic in Indonesia. So Perum LPPNPI must have a precise strategy to maintain aviation safety which is the benchmark for its performance as a Business Entity. Apart from the rejuvenation of flight navigation facilities, the increase in knowledge of the human resources of Perum LPPNPI must also be improved, especially in the operational sector which is in direct contact with service users.

Air traffic service or what we usually hear as Air Traffic Control (ATC) is one of the services served by Perum LPPNPI. With its function as a air traffic control, ATC is at the forefront of Perum LPPNPI to service users.

With the increase in the amount of flight traffic, the workload or workload of air traffic controllers also increases with the road.

Based on the foregoing, the authors conducted pre-research observations and surveys at Perum LPPNPI by interviewing the Head of the Sub Division of Perum LPPNPI Service Planning regarding the company's efforts in dealing with the increasing number of flights. It is known that the increase in the amount of aviation traffic is directly proportional to the increase in the workload of air traffic controllers. 


\section{LITERATURE REVIEW Definition of Strategy}

Strategy is an understanding that concerns matters relating to the ability or failure of a company or organization to face pressures that arise from within or from outside. (Rhenald Kasali, 2005: 99).

Strategy is a design of how to achieve goals based on the current situation (situation). Strategy is an umbrella or summary of the tactics that will be used. Strategy in essence is planning (planning) and management (management) to achieve a goal. From this definition, it can be concluded that strategy is basically a plan to achieve a goal based on current conditions which contains the tactics that will be used in building success in order to obtain the winning power as determined.

Hit, Ireland, Hoskisson (2011) defines strategy as an integrated and coordinated series of commitments and actions designed to exploit key competencies and gain competitive advantage. Meanwhile, according to Barney (2002) defines strategy as a theory of how companies achieve competitive advantages. Strategy provides answers to management about how to achieve company goals and how to achieve the organization's mission and strategic vision.

Pearce and Robinson (1982) in the book Strategic Management develop strategic management steps as follows:

1. Determining the company's mission, including a general statement regarding the purpose of the establishment (purpose), philosophy and goals (goals);

2. Developing a company profile that reflects the internal conditions of the company and its capabilities;

3. Assessment of the company's external environment, both in terms of a competitive spirit and in general;

4. Analysis of the opportunities available from the environment (which give birth to choices);

5. Identification of the desired options that cannot be fulfilled in order to fulfill the demands of the company's mission;

6. Choosing a strategy for long-term objectives and an outline of the strategy needed to achieve these objectives;

7. Develop annual objectives and short-term plans that are in line with long-term objectives and strategic outlines;

8. Implementation of the above by using the resources listed in the budget and marrying the plan with the human resources, structure, technology, and possible remuneration system;

9. Review and evaluation of the things that have been achieved in each short-term period as a process for exercising control and as input for future decision making.

\section{Human Resource Management}

Regarding to human capital Robert L. Mathis, John H. Jackson (2008) states not only with regard to the physical people in the organization but including the abilities, capabilities and skills that are brought and contribute to organizational success. In other words, human capital is the collective value of the abilities, knowledge, skills, life experiences, and motivation of the organizational workforce. 
According to Hasibuan (2013: 9), management is the science and art of regulating the process of utilizing human resources and other resources effectively and efficiently to achieve certain goals, this management consists of six elements $(6 \mathrm{M})$, namely: men, money, method, materials, machines, and market. This men (human) element develops into a field of management science called Human Resource Management which is a translation of man power management. Some of the management that regulates this human element is called personnel management.

Human Resource Management is a process of managing and utilizing HR of a professional company so that all employees are able to develop their potential optimally in their work environment, so that work productivity is maximally achieved. In detail, HR management is a process of planning, organizing, implementing, and controlling HR procurement (HR planning, job analysis, recruitment, job orientation), HR development (training and development, career development performance appraisal), remuneration (salary) , work incentives, welfare program benefits), integration of human resources work (work motivation, work discipline, participation, job satisfaction of job leadership, maintenance of human resources (work communication, occupational health and safety, work conflict control, coaching, work counseling, stress management) and separation of human resources during retirement (Anwar, 2011: 5).

Because of the important role of HR in the implementation and achievement of organizational goals, human resource management must pay attention to several aspects such as aspects of staffing, training and development, motivation and maintenance (Yuniarsih and Suwatno, 2016: 2), because managing HR is a system, so several aspects are involved. It is a concern that in its implementation, it must depend on each other (synergize) with one another, not as an activity that runs separately and because each synergized activity is an implementation of every decision taken. The quality of their synergy contributes to the ability of human resources and organizations to achieve goals.

In achieving goals, every human resource must have competence at work, according to Covey, Roger and Rebecca Merrill (1994) in Anwar (2011: 13), these competencies include:

a) Technical competence: knowledge and expertise to achieve agreed outcomes, the ability to think about problems and look for new alternatives.

b) Conceptual competence: the ability to see the big picture, to test various assumptions, and to modify perspectives.

c) Competence for living and interdependent abilities effectively with others, including the ability to listen, communicate, get third-alternatives, create win-win agreements (win-win solutions), and strive to achieve third alternative solutions, the ability to see and operate effectively in a complete organization or system.

\section{Workload}

Implementation of work effectively and efficiently in an organization to increase the organizational capacity that is professional, transparent, and proportionate requires policies, including those related to the appropriate workload between main tasks and functions in each position in the organization ideally. 


\section{Definition of Workload}

Based on the Regulation of the Minister of Home Affairs Number 12 of 2008 concerning Guidelines for the Analysis of Workloads in the Ministry of Home Affairs and Local Government in Article 1 point 5, workload is the amount of work that must be borne by a position or organizational unit and is the product of the work volume and time norms. According to Hart and Staveland in Tarwaka (2015), workload is something that arises from the interaction between the demands of tasks, the work environment where it is used as a workplace, skills, behavior and perceptions of workers.

According to Hart and Staveland in Tarwaka (2011: 106) that workload is something that arises from the interaction between the demands of the work environment which is used as a workplace, skills and perceptions of workers. Workload is sometimes operationally defined in terms of factors such as the demands of the task or the efforts made to do the job. According to Munandar (2001: 383), workload is a condition of work with job descriptions that must be completed within a certain time limit. Workload can be further differentiated into excessive or too little quantitative workload, which arises as a result of too many or too few tasks given to the workforce to be completed in a certain time, and the workload is excessive or too little qualitative, i.e. if people feel unable to perform a task, or the task does not use the skills and / or potential of the workforce.

\section{Theory of Workload}

According to Manuaba in Tarwaka (2011: 130), workload is influenced by 2 (two) factors, namely as follows:

1) External Factors

Workload external factors are workloads that come from outside the worker's body. This aspect of the external workload is often referred to as a stressor. As for matters that include external workloads are:

a. Tasks

Tasks are physical in nature, such as workspace, work stations, work tools and facilities, working conditions, work attitudes and work aids. There are also mental tasks, such as the complexity of the job and the responsibility for work.

b. Work organization

Work organizations that affect workload, for example, length of work time, rest time, shift work, wage systems, night work, duties and authorities.

c. Work environment

The work environment that can affect the workload is one that is included in the additional burden due to the work environment. For example, physical work environment (lighting, noise, mechanical vibration), chemical work environment (dust, air pollutant gases), biological work environment (bacteria, viruses and parasites) and psychological work environment (labor placement).

2) Internal Factors

Internal workload factors are factors that come from within the body itself as a result of reactions from external workloads. This reaction is known as a strain. In summary, the internal factors include: 
a. Somatic factors, namely gender, age, body size, health condition, nutritional status.

b. Psychological factors, namely motivation, perception, belief, desire, satisfaction, and so on.

According to the Regulation of the Minister of Home Affairs Number 12 of 2008 concerning Guidelines for Workload Analysis in the Ministry of Home Affairs and Local Government, it is explained that workload measurement is carried out to provide several benefits to the organization, namely as follows:

1. Arrangement / improvement of the organizational structure;

2. Assessment of job performance, position and work performance of the unit;

3. Materials for improving work systems and procedures;

4. Facilities for improving institutional performance;

5. Preparation of standard workload for positions / institutions, compilation of list of staff members or materials for determining echelonization of structural positions;

6. Preparation of plans for real employee needs in accordance with the workload of the organization;

7. Employee transfer program from redundant units to underprivileged units;

8. Employee promotion program;

9. Reward and punishment for units or officials;

10. Materials for improving the training program;

11. Material for determining policies for leaders in order to improve the utilization of human resources.

\section{RESEARCH METHODS}

This research is to analyze workload management strategies, constraints in workload management strategies and planning and development of air traffic integration workload management strategies at Perum LPPNP. The research object that the author examines is the Workload Management Strategy of Air Traffic Control at Perum LPPNPI which is located at the Head Office of LPPNPI Perum Jl. Ir. H. Juanda No. 1 Tangerang 15121, Banten Indonesia.

This type of research is a qualitative descriptive study that has a complete picture of a phenomenon or event that occurs according to its purpose. The method used by researchers in analyzing data is data collection, data reduction, data display and conclusion. Subjects in this study were 5 (five) sources as officials on duty at Perum LPPNPI.

\section{FINDINGS AND DISCUSSION History of Perum LPPNPI}

There are 2 (two) things that gave birth to the idea of forming a single provider of navigation services: Multiple tasks carried out by PT Angkasa Pura I (Persero) and PT Angkasa Pura II (Persero). This institution is not only responsible for managing the land sector, in this case airports, with all its subordinate duties, but is also responsible for managing flight navigation. 
International Civil Aviation Organization (ICAO) audit of aviation in Indonesia. From the audit conducted by ICAO, namely ICAO USOAP (Universal Safety Oversight Audit Program and Safety Performance) in 2005 and 2007, ICAO concluded that aviation in Indonesia did not meet the minimum requirements of the International Safety Standard in accordance with ICAO regulations. Then it is recommended that Indonesia establish an agency or institution that specifically handles aviation navigation services.

In September 2009, the draft Government Regulation (RPP) was formulated as the legal basis for the establishment of Perum LPPNPI. On September 13, 2012, President Susilo Bambang Yudhoyono set the RPP to become PP 77/2012 on Public Companies (Perum), the Indonesian Aviation Navigation Service Provider (LPPNPI). This PP is the legal basis for the formation of Perum LPPNPI. After the issuance of PP 77/2012 on Perum LPPNPI, navigation services previously managed by PT Angkasa Pura I (Persero) and PT Angkasa Pura II (Persero) and UPT were handed over to Perum LPPNPI or better known as AirNav Indonesia. As of January 16, 2013 at 22:00 WIB, all navigation services managed by PT Angkasa Pura I (Persero) and PT Angkasa Pura II (Persero) were transferred to AirNav Indonesia. 22:00 WIB was chosen because of the difference in three times in Indonesia, namely WIB, WITA and WIT. 22:00 WIB means exactly 24:00 WIT or exactly the change of day so that aircraft passing through Eastern Indonesia at 00:01 WIT or January 17 2013, the management has entered AirNav Indonesia. Since then, all navigation services at 26 airports managed by PT Angkasa Pura I (Persero) and PT Angkasa Pura II (Persero) have been officially transferred to AirNav Indonesia, as well as human resources and equipment.

With the establishment of AirNav Indonesia, safety and flight navigation services can be well organized because previously navigation services in Indonesia were served by several agencies, namely UPT Directorate General of Transportation, PT Angkasa Pura I (Persero), PT Angkasa Pura II (Persero), and special airports. resulting in differences in the level of quality of navigation services and the lack of focus of flight navigation service providers. AirNav Indonesia's capital ownership is fully owned by the Republic of Indonesia, which in this case is represented by the Ministry of BUMN. Meanwhile, the Ministry of Transportation acts as a regulator for AirNav Indonesia. As a Public Company that aims to improve flight navigation services in Indonesia, AirNav Indonesia carries out a Business Process by means of Cost Recovery.

AirNav Indonesia is divided into 2 air spaces based on the Flight Information Region (FIR), namely FIR Jakarta which is centered at the JATSC Branch Office (Jakarta Air Traffic Services Center) and FIR Ujung Pandang which is centered at the MATSC Branch Office (Makassar Air Traffic Services Center). AirNav Indonesia is a milestone in the world of Indonesian national aviation, because AirNav Indonesia is the only flight navigation operator in Indonesia.

\section{Business Field of Perum LPPNPI}

Based on PP. 77 of 2012 the purpose and objective of establishing Perum LPPNPI is to provide aviation navigation services in accordance with applicable standards to achieve flight efficiency and effectiveness in the national and international scope. As a Business Entity, AirNav Indonesia's performance benchmarks are seen from the safety side which consists of many elements such as human resources, equipment, procedures and so on, all of which must 
follow developments and standards that are strictly regulated in the Civil Aviation Safety Regulations (CASR).

\section{Vision and Mission of Perum LPPNPI}

A vision is a distant view of a company or institution and others, a vision can also be interpreted as the goals of a company or institution and what must be done to achieve these goals in the future or in the future. The vision cannot be written more clearly because it explains the detailed picture of the system it is aiming at, this is due to changes in science and situations that are difficult to predict over a long period of time.

Below are some of the requirements that should be met by a vision statement, including:

- Forward oriented.

- Not based on current conditions.

- Expressing creativity.

- Based on the principles of values that contain respect for society.

Mission is a statement about what a company or institution must do in an effort to realize this vision. Company mission is defined as the purpose and reason why the company or institution was created. The mission will also provide direction as well as boundaries for the process of achieving goals.

The Vision and Mission of Perum LPPNPI are:

\section{VISION}

" To become an international standard aviation navigation service provider".

\section{MISSION}

" Providing flight navigation services that prioritize safety, flight efficiency and environmental friendliness in order to meet service users' expectations".

\section{Overview of Key Informant}

The key informant of this research include people who are considered to have a direct connection or are considered to understand the operational activities of Air Traffic Control at Perum LPPNPI. Based on this, the authors determine the sources of this study as follows:

Tabel 4.1 Key Informant

\begin{tabular}{|c|l|l|l|}
\hline No & Name/Initial & Position & Remarks \\
\hline $\mathbf{1}$ & WT & $\begin{array}{l}\text { Sub Division Of Operation } \\
\text { Control Of The } \\
\text { Communication Service } \\
\text { Flight And Personnel } \\
\text { Operations }\end{array}$ & $\begin{array}{l}\text { Member of Indonesia Air Traffic } \\
\text { Controllers Association (IATCA) }\end{array}$ \\
\hline $\mathbf{2}$ & SA & Head Sub Division Of & Member of Indonesia Air Traffic \\
\hline
\end{tabular}




\begin{tabular}{|c|l|l|l|}
\hline & & Planning Services & Controllers Association (IATCA) \\
\hline $\mathbf{3}$ & RW & $\begin{array}{l}\text { Manager ATFM \& CDM } \\
\text { Planning }\end{array}$ & $\begin{array}{l}\text { Member of Indonesia Air Traffic } \\
\text { Controllers Association (IATCA) }\end{array}$ \\
\hline $\mathbf{4}$ & AM & $\begin{array}{l}\text { Manager Control and } \\
\text { Evaluation of Personnel } \\
\text { Operations }\end{array}$ & $\begin{array}{l}\text { Member of Indonesia Air Traffic } \\
\text { Controllers Association (IATCA) }\end{array}$ \\
\hline $\mathbf{5}$ & ZA & $\begin{array}{l}\text { Junior Manager planning } \\
\text { ATFM }\end{array}$ & $\begin{array}{l}\text { Member of Indonesia Air Traffic } \\
\text { Controllers Association (IATCA) }\end{array}$ \\
\hline
\end{tabular}

Source: author (2020)

\section{Research Results \\ Strategy for Managing Workloads of Air Traffic Control at Perum LPPNPI}

The current condition of Perum LPPNPI is experiencing an increase in the number of flight traffic resulting in an increase in the workload of air traffic controllers. The strategy carried out by Perum LPPNPI is to equalize the amount of flight traffic using the demand and capacity balancing method by issuing a Notice of Airport Capacity (NAC) which can be used by parties involved in leveling flight traffic and optimizing existing resources. Fulfillment of air traffic guidance resources by referring to the Civil Aviation Safety Regulation part 69 (CASR 69) for branches that have not been fulfilled, but in terms of guidance hours are still in accordance with regulations, namely no more than 8 hours of guidance per day. Carry out a performance check every 6 months in accordance with the regulations and understanding of the Standard Operation Procedure (SOP) in improving air traffic services. Increased Surveillance with the implementation of ADS-B and TMA services in 12 locations to become Surveillance.

\section{Constraints in Implementing Strategy for Managing Workloads of Air Traffic Control at Perum LPPNPI}

The productivity of air traffic controllers is still below optimal according to the rules of the Civil Aviation Service Regulation part 69 (CASR 69). The human resource training pattern is not yet effective because it has not been assisted by a system for its management, and is not well controlled for each personnel in participating in training every year. Fulfilling the needs for air traffic control personnel is very dependent on educational institutions under the Ministry of Transportation so that in meeting the deviation of personnel shortages, one must wait for the availability of graduates from related educational institutions. Fulfillment of flight navigation facilities is carried out by the procurement method which requires a long time to meet the needs of air traffic guidance facilities. The understanding of stakeholders regarding demand and capacity balancing is still an obstacle.

\section{Planning \& Development for Strategy for Managing Workloads of Air Traffic Control at Perum LPPNPI}

In the future, Perum LPPNPI will implement a Fatigue Risk Management System (FRMS), which is a risk-based control system to identify, monitor, manage the risk of fatigue with the aim of ensuring that air traffic controllers perform with an adequate level of 
vigilance. Implementation of Air Traffic Flow Management (ATFM) which is useful for more regular, well-predicted flight traffic. Raising Indonesia's status in the Asia Pacific Multi Nodal ATFM to level 3. Restructuring the air space so that conflicts between air traffic are no longer tactical but can also be anticipated on the previous day and even a few months before.

\section{CONCLUSION}

From the results of the research that has been done, the authors conclude as follows:

1. Since the beginning, Perum LPPNPI was established, the need for air traffic guiding human resources was increasingly fulfilled. However, the current condition is that there is still a margin between the needs and the number of human resources owned by Perum LPPNPI in accordance with applicable regulations in Indonesia.

2. Airspace restructuring is a long-term strategy for Perum LPPNPI. This is important in regulating flight routes and airspace sectorization so as to anticipate conflicts between aviation traffic that are not only tactical in nature, but also increase predictability in the days to months before. So that air traffic controllers can predict well the traffic that will be managed.

3. Perum LPPNPI as the air navigation service provider in Indonesia has become part of the Asia Pacific Multi Nodal ATFM with level 2 status, at this level Indonesia in managing foreign traffic must meet the Calculated Take-Off Time (CTOT) from the destination airport or departure from overseas whose country status is level 3.

4. Fatigue in conducting flight traffic guidance can affect safety, productivity and efficiency. By implementing the Fatigue Risk Management System (FRMS), Perum LPPNPI can see, reduce and manage fatigue to improve flight navigation services and ensure flight safety.

\section{REFERENCE}

Dessler, Gary. (2016). "Human Resource Management. 15 ${ }^{\text {th }}$ ed. Pearson". New Jersey.

Fahmi, Irham. (2017). Manajemen Sumber Daya Manusia Teori dan Aplikasi. Bandung: Alfabeta.

Hasibuan, Malayu. S. (2013). Manajemen Sumber Daya Manusia. Jakarta: Bumi Aksara.

Kadarisman. (2012). Manajemen Pengembangan Sumber Daya Manusia. Raja Grafindo Persada. Jakarta.

Kasmir. (2016). "Manajemen Sumber Daya Manusia (Teori and Praktik)". Raja Grafindo Persada. Jakarta.

Mangkunegara, Anwar Prabu. (2011). Manajemen SDM Global. Jakarta: Mercu Buana.

Marwansyah. (2016). Manajemen Sumber Daya Manusia. Bandung: Alfabeta.

Mathis, Robert L. and Jackson John H. (2010). "Human Resource Management $13^{\text {th }}$ ed.Thomson". South-Western.

Mondy, R. Wayne and Martocchio, Joseph J. (2016). "Human Resource Management. 14 ed. Pearson". London.

Miles,M.B, Huberman,A.M, dan Saldana,J. (2014 ). Qualitative Data Analysis, A Methods Sourcebook, Edition 3. USA: Sage Publications. Terjemahan Tjetjep Rohindi Rohidi, UIPress.

Moleong, Lexy J. (2004). Metode Penelitian Kualitatif. PT. Remaja Rosdakarya. Pearce, Jhon dan Robinson. (2007). Manajemen Strategis.Salemba Humanika. Jakarta. 
Noe, Raymond A., et all. (2014). "Human Resource Management Mc Graw-Hill", New York Priansa, D. J. (2014). Perencanaan dan Pengembangan Sumber Daya Manusia. Bandung: Alfabeta.

Rahayuni, A. Y. (2013). Manejemen Perubahan dan Invasi. Jakarta: UI Press.

Sugiono. (2011). Metode penelitian kuantitatif kualitatif dan $R$ dan D. Bandung: Alfbeta.

Sunyoto. Andang. (2012). Teori, Kuesioner and Analisis Data Source Daya Manusia. Center for Academic Publishing Service. Yogyakarta.

Sutrisno, Edy. (2017). Manajemen Sumber Daya Manusia. Jakarta: Kencana.

Suwitno., Priansa, Donni Juni. (2016). Manajemen SDM dalam Organisasi Publik dan Bisnis. Bandung: Alfabeta.

Yuniarsih, T., \& Suwanto. (2016). Manajemen Sumber Daya Manusia. Bandung: Alfabeta.

Raco, J R. (2010). Metode Penelitian Kualitatif (Jenis, Karakteristik, dan keunggulannya). Jakarta: PT Gramedia Widiasarana Indonesia.

Yin, Robert K. (2012). Studi Kasus Desain \& Metode. PT. Raja Grafindo Persada. Jakarta. 